\title{
Price Discounts in Rights Issues: Why Do Managers Insist On What Investors Hate?
}

\author{
Jorge Farinha ${ }^{\mathrm{a}}$ \\ Cesário Mateus ${ }^{\mathrm{b}}$ \\ Nuno Soares ${ }^{c}$
}

Keywords: rights issues, market efficiency, equity financing JEL: G14, G32

${ }^{\text {a }}$ CEF.UP*, Porto Business School and Faculdade de Economia, Universidade do Porto. Email: jbfarinha@pbs.up.pt

${ }^{\mathrm{b}}$ University of Greenwich Business School. Email: c.mateus@greenwich.ac.uk

${ }^{\mathrm{c}}$ CEF.UP*, Faculdade de Engenharia, Universidade do Porto. Email: ndsoares@ @e.up.pt

*CEF.UP - Center for Economics and Finance at the University of Porto is supported by Fundação para a Ciência e Tecnologia (FCT), Portugal.

Forthcoming, European Business Review 


\title{
Price Discounts in Rights Issues: Why Do Managers Insist On What Investors Hate?
}

\begin{abstract}
We analyse the causes and impact of the significant mean price discounts $(25 \%$ for financial and $29 \%$ for non-financial firms) in rights issues in the UK using a sample of 268 observations for the period of 1994 to 2012. We observe that for non-financial companies the issue terms announcement returns are negatively affected by the discount size, while firm size, growth prospects and good previous stock performance have a positive impact. We also investigate which factors seem to influence managers to engage in deeper discounts when these are so disliked by investors. Evidence is provided that firms with more leverage, larger bid-ask spreads or suffering losses tend to choose deeper discounts. We conclude that managers balance the expected negative reaction of the market to a price discount with the risks of a costly issue failure, with these being higher when the firm experiences losses, has a higher volatility and also when the stock market climate is more adverse.
\end{abstract}

Keywords: rights issues, market efficiency, equity financing JEL: G14, G32 


\section{Introduction and motivation}

On 23 September 2014, Mothercare's shareholders were told that they would be able to buy, in a $£ 100$ million rights issue, 9 new shares for each 10 shares already owned with a discount of 34 percent to preannouncement stock price. The shares ended up - $2 \%$ lower on that day.

In contrast, in September 2009, two large UK housebuilders, Barratt Developments and Redrow, simultaneously launched two rights issues to raise a total of almost $£ 850 \mathrm{~m}$ in equity. In both cases the firms set up subscription terms at a heavier discount from closing prices before the announcement (63\% and 55\%, respectively). Commenting on this issue, an analyst observed that "the size of the discounts to the market price shows how much these companies wanted the money" (Flanagan, 2009). These announcements were followed by quite more significant falls in share prices than in the case or Mothercare (three-day drops of $-8 \%$ and $9 \%$, respectively)

Analysing RPC Group' s announced discounted rights issues, the Financial Times Online (29 January, 2016) observed that "shareholders generally don't like the way rights issues force them either to stump up cash or see their existing holding diluted." In accordance with this, as Societé Générale, a French financial institution, announced in February 2008 a $£ 4.1$ billion ( $€ 5.5$ billion) rights issue, with a discount priced on the new shares of around $39 \%$, an analyst noted that, "as they can't afford this operation to go wrong, they've decided to hit very low" (Times Online, February 12, 2008). As the Office of Fair Trading (2011, p. 25) points out, "company executives are also keen to avoid the perception by the stock market of financial weakness and a lack of shareholder support that non-underwritten deeply discounted issues are sometimes associated with".

Up until the 90s, rights issues were "the norm in the UK and the rest of Europe" (Armitage, 1998, p. 31). While rights issues have seen their importance gradually fall in the UK since the $90 \mathrm{~s}$, there were still about 20 rights issues per year in the first decade of the $21^{\text {st }}$ century (Armitage, 2007) and these are still one of the most common form of seasoned equity issues after open offers (Armitage, 2007). Even though in theory price discounts in rights issues should not matter (Armitage, $1998^{1}$ ), the examples above suggest that the market seems to view the existence of price discounts in rights offers as a significant negative signal about the

\footnotetext{
1 "Assuming no difference in market response and transaction costs between different levels of discount, the wealth of shareholders is unaffected by the depth of discount or by whether or not they sell their rights" (Armitage, 1998, p. 50).
} 
success of the rights issues and/or the future financial performance of the issuing firm. In this paper we seek to empirically address this topic, by first analysing whether it is in fact true that, unlike standard theory, and after controlling for other factors, the definition of the selling price for new shares issued to existing shareholders through a rights offering can be a value relevant decision. We also investigate whether there are any differences in this regard between financial and non-financial firms.

Our major concern in this paper, however, is to examine why, if price discounts in fact command a significant negative impact on share prices, do managers still engage in significant price cuttings. To our knowledge, this is the first paper that seeks to identify the key factors that have an influence on the decision to set up a specific price discount. We also provide an analysis that splits firms between financial and non-financial to look for potential differences in the way these factors impact on the discount decision. Given the distinctive higher importance, due to its specific regulatory environment, of meeting equity capital ratios in the financial sector in comparison with other industries, we anticipate that meeting capital requirements generate particular benefits to financial companies that can reduce other potentially adverse signals coming from deep discounts in rights issues.

Our results show a number of interesting conclusions. First, in spite of the significant negative market reaction that we observe to the announcement of price discounts, there are indeed relevant differences between financial and non-financial firms. Specifically, we do not observe for the latter the same statistically significant impact of prices discounts on the announcement returns as we do for non-financial companies. Second, we document evidence consistent with the idea that managers balance the expected negative reaction of the market to a price discount with the risks and costs of an issue failure, with these being potentially higher when the firm experiences losses, has higher volatility and also when the stock market climate is more adverse. Our findings also again reveal some differences between financial and non-financial firms. For the former we provide evidence that firms with more leverage, larger bid-ask spreads or suffering losses tend to choose deeper discounts. In the case of financial institutions, however, although bid-ask spreads and losses also have a similar impact, leverage does not have a statistically significant influence on price discounts.

The remainder of paper is structured as follows. First we provide a literature review and present our major research hypothesis. Section 3 then proceeds to describe the sample and the 
methodology used. The following section presents the empirical results and in section 5 we provide the main conclusions.

\section{Literature review and research questions}

In a rights issue, shareholders of listed companies that decide to issue new equity capital are given an instrument (the "rights") that entitles them to exercise a free option to acquire new shares at a predefined price, typically below the preannouncement stock price. In contrast, in an open offer, currently the most used seasoned equity issue form in the UK, shares issued are privately placed before being offered pro-rata to existing shareholders. Thus, in sharp contrast to rights issues, shareholders cannot sell their entitlements in an open offer (Armitage, 2007). Contrary to other seasoned equity issues, Espenlaub et al (2009) show that the market reaction to open offers is a positive one.

In theory, as long as the price at which the new shares are sold is lower than the stock price prior to the equity issue, the pricing of the new shares should be irrelevant ${ }^{2}$. In fact, shareholders can either (i) exercise their rights and buy the new shares, enjoying a positive difference between the ex-rights stock price and one at which they bought the new shares, or simply (ii) cash in the value of their rights by selling these in the open market. Assuming market efficiency, in the first case their apparent gain should be matched by a corresponding drop in the price of the old shares upon the exercise of the rights. In the second case, the amount received from the sale of the rights should also be equal to the capital loss in the old shares $^{3}$. Consistent with this reasoning, standard finance textbooks (see for example, Brigham, 2006 ) typically mention that any discount made in relation to the current stock price should be perfectly matched by an increase in the value of the rights that each shareholder will receive, leaving its total wealth unchanged.

However, it is a well-established fact that the announcement of rights issues in the UK is generally seen as bad news by investors in the stock market (see for example Armitage, 1998, Burton et al., 2000, and Slovin et al., 2000). Similar results have also been found for other

\footnotetext{
${ }^{2}$ If the price was set above the current stock price, nobody would be willing to acquire neither the new shares nor the corresponding rights.

${ }^{3}$ One should note that the ex-rights price should be equal to the market capitalisation of the firm's shares after the announcement plus the cash proceeds of the new issue divided by the total number of shares after the conclusion of the issue.
} 
countries (see for example Singh, 1997 for the US, Marsden, 2000 in New Zealand, Kabir and Roosenboom, 2003 for the Netherlands or Ginglinger et al, 2013 for France).

In addition to this evidence, and as the examples in the prior section show, it is a common perception among finance practitioners that heavily discounted new shares issued in rights offerings can be a particularly negative signal for the value of the company.

A possible reason for the practitioners' apparent nervousness when the selling price is set at a low level is that the company's attitude may reflect its view that, if no sufficient discount is made, there is a higher likelihood that the rights-on price might fall to a level too close to the price of the new shares, potentially jeopardizing the success of the issue. As such, investors may feel that managers engage in deep discounts when they believe that current share prices are overvalued (Armitage, 1998) and thus react accordingly in the market when such issue terms are announced. Managers in practice have to strike a balance between the costs of a bad signal given to the market arising from a price which was set at low levels with the benefits of that discount. One may reason that if no discount was made, a huge risk could occur that the investors do not take up the shares in the face of any potential market-wide movements that could negatively affect the current stock price.

Also, market participants frequently view the existence of deep discount in rights offerings "as a coercive way for a company to raise money", given that such a deep discount makes it prohibitively expensive not to exercise the right (Bohren et al, 2007).

Such concern about a heavy discount on the price of the new shares, if any, should matter however much more in the case of open offers than in rights issues. In an open offer, if a shareholder does not have the financial means to acquire the new shares, he/she will either suffer a direct loss (if no new shares are bought) or at the very least engage in additional costs (and financial risks) by obtaining cash through loans or other sources to finance the acquisition of the new securities. In contrast, if a shareholder receives tradable rights he/she will avoid this altogether as long as there is a sufficiently liquid market to sell those rights. Therefore, in a rights issue one would not anticipate that the size of discounts should matter unlike the case for open offers where the only alternative to avoid losses is to invest in more shares, which for some may not be either feasible or possible at very low cost. Thus in rights issues, and in remarkable contrast to open offers, only irrational investors would not be able

\footnotetext{
${ }^{4}$ Posted in www.fool.com, 12.07.2007.
} 
to counterbalance the losses arising from the drop in share prices upon the completion of the share issue. As Armitage (2007, p. 1346) points out, "because the entitlements cannot be sold, a discount means that wealth is transferred to the placees from the non-subscribing shareholders ". We therefore focus in this research our attention only on rights issues, where, unlike open offers, and apart from the signalling issues already mentioned above, in theory discounts should not matter for rational investors ${ }^{5}$.

Balachandran et al (2009) analyse the market impact of rights offerings terms announcements in Australia and find that the market reaction to rights issues is particularly negative in issues characterised by high price discounts. The authors acknowledge that managers tend to signal the quality of their firm by the choice of rights issues method and argue that lower-quality firms tend to use only partial standby agreements by underwriters and large subscription price discounts, whereas higher quality ones tend to use full standby rights issues agreements by underwriters with relatively low price discounts. As the authors also observe, an additional factor that is relevant for the potential market reaction to the announcement of a rights offering is whether the issue is insured by underwriters or not. In other words, if the risk of issue failure is minimized because underwriters provided a standby agreement to take up any nonsubscribed shares, then one could anticipate that the perception of firm quality by the market will be more positive than that of an uninsured issue, and so a large price discount in such case would not have such potential negative impact.

In the UK, although non-pre-emptive equity issues are possible, companies raise most of their new equity capital under pre-emptive conditions whereby shares are offered to existing shareholders in proportion to their shareholdings. Within pre-emptive equity raising, companies mostly use underwritten rights issues (Marsh, 1980, Levis, 1995, Capstaff and Fletcher, 2011). Although possible in theory, there are in practice very few instances of nonunderwritten new equity issues (Office of Fair Trading, 2011).

To explain the apparent puzzle where managers choose price discounts that investors dislike, Heinkel and Schwartz (1986) derive a model for equity issue type choice model where, due to asymmetric information, high quality firms signal their value by choosing rights issues with

\footnotetext{
${ }^{5}$ A possible exception, however, which has been pointed out by Armitage (2007) is that it may be costly to sell large blocks of rights. However, even with this potential cost, price discounts in rights issues are still arguably much less costly or important than those occurring in open offers where shareholders receive only non-tradable rights, therefore exposing themselves to potentially large losses. In 1999 document, the UK Monopolies and Mergers Commission, even though expressing some concerns about the liquidity of the market for rights concluded in favour of the inexistence of substantial costs in the sale of rights in the market, with some exception for very illiquid shares.
} 
low discounts and standby underwriting agreements. Consistent with that model, Slovin et al (2000) report results for the period 1986-94 in the UK where price discounts have a negative impact on firm value. However, prior to 1986 (when major deregulation changes in the Stock Exchange regulations occurred), they observed no negative impact of the subscription price discount on share prices.

There is a large US-based literature on Secondary Equity Offerings (SEOs) that has in analysed, among many other aspects, the impact of price discounts. Some of the factors that have been observed to influence the price discounts of the new shares are the pre-issue return volatility of the issuing firm, the relative size of the offer (Corwin, 2003). Price discounts in these SEOs are typically in the region of $2 \%$ (Corwin, 2003). The existing literature presents a number of theoretical arguments to explain this apparent underpricing of SEOs that include uncertainty and asymmetrical information (ex. Rock, 1986; Beatty and Ritter, 1986), price pressure (Scholes, 1972), manipulative trading (Gerard and Nanda, 1993), transaction cost savings (Loderer et al, 1991) and underwriting practices (Lee et al, 1996). However, in the typical SEOs that take place in the US, shares are not offered to existing shareholders but to the general public. As such, practicing discounts in the pricing of new shares creates a direct cost to existing shareholders, in contrast with rights issues (and, to a lesser extent, open offers in the UK). In general terms SEO pricing in the US is thought to results from the interaction between the demand and supply curves for new shares (where the demand is driven mostly by outside investors) and any factors than can influence the price elasticity associated to these curves (Gao and Ritter, 2010; Huang, and Zhang, 2011). We therefore regard the question of price setting in SEOs in the US as being essentially distinct from that of equity issues carried out through rights offerings. This is also the reason that we do not take into account in our analysis private placements, in addition to the already excluded open offers.

Given most likely the fact that in the US rights issues are very rare, existing empirical literature in this area is scarce and, above all, no field research has yet examined to our knowledge the specific factors that influence managers to choose a heavily discounted price for the new securities issued through rights offering in spite of the potential adverse effects on a firm's stock price.

In this paper we look at evidence from the UK, where, unlike in the US, pro-rata issuance of new shares to existing shareholders is the norm, rather than the exception, for seasoned equity issues and where rights issues in particular have an importance. We test not only whether the 
market reacts more negatively to the announcement of a rights issue when the selling price is set at a large discount from current stock prices, but also analyse the factors that influence a managerial decision to set up a particular discount. Prior research is not unambiguous as for example Slovin et al (2000) in the UK found that for 1986-94 the price discount has a negative impact on announcement returns, consistent with investors viewing it as a negative signal of firm value, but the same was not observed in their study for the period before 1986 . Armitage (2002), however, observes a negative impact of discounts on the market reaction to the terms of the rights offering.

We extend the existing research in a number of ways. Similarly to extant literature, we look at more recent evidence (1994-2012) but also test a number of different variables that can influence the market reaction to price discounts can be more or less severe contingent on the firm's characteristics. Second, and more importantly, we examine the factors that have a potential influence on the manager's decision to set up a particular level of price discount to the new shares and whether these are different between financial and non-financial firms.

We anticipate that the managerial decision to set up a larger price discount is likely to be influenced by the level of debt in a company or the existence of losses. In fact, in a more leveraged and/or loss-making company the costs of an unsuccessful rights offering may be especially high as this can increase the likelihood of corporate failure (Altman, 1968). In this context a heavily discounted offer may increase the success of the rights issue.

In the case of financial firms, their regulatory environment imposes very strict rules regarding the existence of a minimum level of equity capital. Companies failing to comply with this requirement face a severe risk of a regulatory intervention (eg, a bailout) if not straight liquidation or an acquisition by third party as a last resort way for avoiding bankruptcy. Therefore, for these institutions, ensuring the success of an equity issue can be far more important than to non-financial firms. As Bohren et al (1997) assert, because of their capital requirements, equity issues in banks (and insurance companies) have different characteristics from those of non-financial firms (and have more predictable equity issues than these) and therefore should not be analysed jointly. Also Dahl and Shrives (1990) show that regulatory minimum capital requirements are a direct cause for equity issues in banks, thus suggesting that the risk of an issue failure can be far more severe in this industry than in the nonfinancial sector. Given this different regulatory environment and the fact that the debt levels (one of our determinants of price discounts) of financial firms are usually much higher than 
non-financial ones, we provide in our research separate analyses for these two types of companies. For financial firms, one can argue that price discounts could be on one hand higher than for non-financial firms due to the potentially more dire consequences of equity issue failures. However, if the perceived benefits of an equity issue are usually more clear in financial companies (they are required by their regulatory environment) then it could be that shareholders may not need a very high discount to be enticed to subscribe the new shares. Therefore, it is ultimately an empirical issue. A similar reasoning applies to the market reaction to the announcement of the terms of an equity issue in the case of financial institutions. Higher price discounts in financial firm rights issues may be either seen unfavourably by the market but also could be more welcomed than in non-financial firms if it reassures shareholders that the risk of an equity issue failure (and of a subsequent regulatory intervention, bailout or last resort acquisition by an external party) is minimized.

However, there are also other potentially important factors that managers may take into consideration. As suggested above, firms whose stock price is more volatile may be more at risk of a downward share price movement that could endanger the success of a rights offering if no sufficiently high discount is made on the new shares. Since shares with larger bid-ask spreads are usually perceived as having greater volatility or being less liquid (Copeland and Galai, 1983), we would expect that bid-ask spread should have a positive impact on the size of the price discount of the new shares. Similarly, if the offer is made at a time of a bear market, managers may sense also a higher risk that, due to market-wide movements, the share price might drop below the price set up for the new shares, in which case the rights issues would become unattractive to investors. Consistent with this assertion, Levis (1995) suggests that managers may time the announcement of a seasoned equity offering for after a period of significant rises in stock prices.

Whether the above factors are indeed important in practice for managers when setting up the terms of a rights offering is then mostly an empirical issue which we seek to address in this paper.

In addition to determining the cause of discounts, we also formally analyse the hypothesis that, due to an unfavourable signal conveyed by a large price discount, there will be a negative reaction from investors to the announcement of the rights issues price terms. However, when these share issues take place in companies perceived by investors as more profitable, with better growth opportunities, or in instances where the recent stock 
performance of the company has been good, such reaction is likely to be more positive (see Eckbo and Masulis, 1995, for a survey of the valuation effects of SEO announcements). Finally, we expect that in firms whose ownership is more concentrated, the reaction to the announcement of the terms of the share issue may be more negative given the potential for minority shareholders wealth appropriation by majority owners (La Porta et al, 2000).

\section{Sample, methodology and summary statistics}

\subsection{Sample}

Data collection starts by retrieving a list of rights issues deals, their details and identifiers from Thomson OneBanker deals module. Only deals for stocks traded at the London Stock Exchange and traded in British pounds are considered. Each deal is then verified using the London Share Price Database and Datastream capital changes module information and those that are not confirmed in both these databases are excluded from the analysis. Given that Thomson OneBanker does not provide the exchange rate information for each deal, we use the information provided by the Datastream capital changes module. Finally, only firms that have information in both Datastream for daily market data and Worldscope for accounting data are included in the final sample. After this process, the final sample is comprised by 268 rights issues deals that occurred during the period of 1994-122012, with 32232 and 636 deals for non-financial and financial firms, respectively.

\subsection{Methodology}

\subsubsection{Pre-announcement causes for discount and market reaction}

The analysis as discussed previously is divided in two stages. In a first step (thereafter preannouncement) we evaluate the firm's and market conditions that determine the price discount. In a second stage (in what we term the post-announcement period) we measure the market reaction to the rights issues announcement by calculating the Abnormal Announcement Returns $(A A R)$ by cumulating the difference between daily returns $(R)$ and expected market returns $(E R)$ for the period of -2 to 2 relative to the announcement day, 
following the approach implemented by Iqbal (2008). This is done with a set of variables which includes, besides others, the price discount offered in the right issue ${ }^{10}$.

\subsubsection{Pre- announcement causes for price discounts}

We apply both multiple OLS cross-section and ordered probit regressions in our analysis. This allows determining the effect of firm's characteristics and market conditions on the price discount but also, and more importantly, to provide information regarding the probability of the price discount range. The models are defined as follows:

Price Discount $_{i, t}=\alpha++\beta_{1}$ Leverage $_{i, t}+\beta_{2}$ Bid $_{A s k_{i, t}}+\beta_{3}$ Loss $_{i, t}+\beta_{4} M_{-}$Sentiment $_{i, t}+\varepsilon_{i, t}$

and,

$$
\text { Price Discount }=\left\{\begin{array}{c}
0 \text { if Price Discount } \leq \mu_{1} \\
1 \text { if } \mu_{1}<\text { Price Discount } \leq \mu_{2} \\
2 \text { if Price Discount }>\mu_{2}
\end{array}\right.
$$

where $\mu_{1}$ and $\mu_{2}$ are the cut-off points ${ }^{11}$. PRICE DISCOUNT is the discount relative to the last available stock price and defined as one minus the issue price divided by the last available price. A higher price discount consistent with investors viewing it as a negative signal of firm value should impact negatively post-announcement returns.

LEVERAGE is calculated as total debt to total assets ratio. As discussed in section 2, one expects higher leveraged firms will be under more pressure to offer larger price discounts to ensure the success of the share offering. Under another perspective, more leveraged firms will usually present higher volatility of stock returns (Christie, 1982) and therefore a greater likelihood of an adverse movement in stock prices that can endanger the success of the share issue, urging firms to set up a greater price discount in the new shares. Therefore, a positive relationship between firm's debt levels and the price discount is anticipated. BID_ASK is the bid-ask price before the announcement of the rights offer terms and is defined as the Ask price minus Bid price divided by the midpoint of the ask and bid prices averaged over the previous year. As previously discussed and suggested by Copeland and Galai (1983), we take the bid-ask spread as a proxy for the riskiness or volatility of the share price and expect the price discount to be greater for firms with relatively large bid-ask spreads due, once again, to

\footnotetext{
${ }^{10}$ Heckman correction test confirms that there is no selection bias. The explanatory variables used for the price discount are not relevant for the $C A R$ regression.

${ }^{11}$ Price discounts are divided by terciles.
} 
the greater risk that the stock price will fall below the subscription price thus endangering the success of the offering. LOSS is a binary variable equal to one if last year's return on assets is negative and zero otherwise. We expect that firms with previous year negative return on assets will be under greater financial pressure due to the danger of bankruptcy (Altman, 1968) and will thus tend to offer higher price discounts to minimize the risk of an equity issue failure. Finally, M_SENTIMENT represents last year's market sentiment and is defined as a binary variable equal to one if last year's market return (previous to the right issue announcement) is positive and zero otherwise. Generally consistent with Levis (1995) finding that managers schedule SEOs after observing a period of rising stock prices, we anticipate that a "good" market sentiment will induce firms to practice a lower price discount as these perceive a lower risk of a market downfall, therefore it is expected a negative relation between market sentiment and price discount. Table 1 summarizes the variables calculation and expected relationship with price discounts.

\section{[Please insert Table 1 here]}

\subsubsection{Market reaction to price discounts}

We also analyse the post-announcement effect on the cumulative abnormal returns (thereafter $C A R$ ) around the announcement of the right issues terms. The abnormal announcement returns is calculated as follows:

$$
A A R_{i, t}=\sum_{t=-2}^{2}\left(R_{i, t}-E R_{i, t}\right)
$$

where $i$ and $t$ represents firm and number of trading days before and after the announcement day, respectively. Calculation of expected returns is based on the market model which is estimated for the period -260 to -20 days before the announcement date, using the FTSE All Shares index return as a proxy for market returns.

The model is described as follows:

$$
\begin{aligned}
& \text { CAR }_{\text {RIGHTS }} i, t=\alpha++\beta_{1} \text { Price Discount }_{i, t}+\beta_{2} \text { Size }_{i, t}+\beta_{3} \text { ROA }_{i, t}+\beta_{4} \text { TOBIN }_{i, t} \\
& +\beta_{5} C_{-} \text {Held_Shares } \\
& i, t
\end{aligned}
$$


where CAR_RIGHTS is the cumulative abnormal returns for the event window (-2 to 2 ) observed in the market around the announcement date of the rights issues offer. PRICE DISCOUNT is the discount relative to the last available stock price and defined as one minus the issue price divided by the last available price. It is expected a negative relationship with the observed cumulative abnormal returns due to the negative information to the market provided by a large price discount. SIZE is calculated as the natural logarithm of firm market value at the day prior to the announcement. Larger firms are more visible to the market due for example by more frequently raising capital. Therefore a favourable (or less negative) response from the market can be expected following rights issues offerings and thus a positive relation between firm size and cumulative abnormal returns is anticipated. ROA is defined as net income over total assets. It is likely that for more profitable firms the market reaction to equity issues will be more favourable, thus suggesting a positive sign for this variable. TOBIN's $Q$ is a proxy for future growth opportunities and is defined as the ratio between the sum of the market value of equity and the book value of debt over the book value of equity and debt. For firms with better growth opportunities, it is expected that the market will react more positively to the announcement of share issues (Eckbo and Masulis, 1995). C_HELD_SHARES represents the percentage of shares held by majority shareholders. For more concentrated firms, with the possibility of conflicts of interest between minority and majority shareholders (La Porta et al, 2000), investors may react more negatively to share issues where the control is maintained by a small group of shareholders. However, a large free float may also be associated to potential manager-shareholder conflicts (Maug, 1998), in which case a large free float could be associated with a more negative reaction by the market to the announcement of the rights offer terms. We thus expect an ambiguous sign for this variable. Finally, F_SENTIMENT represents the investor sentiment to the announcement of share issues and is proxied by a binary variable equal to one if the firm's cumulative market return in the 90 days prior to the announcement is positive and zero otherwise. We expect that a positive sentiment will positively impact the cumulative abnormal returns around the announcement data.

Table 2 summarizes the variables definition and expected relationship with the cumulative abnormal returns around the announcement of right issues terms.

[Please insert Table 2 here] 


\subsection{Summary Statistics}

In table 3 (panels A and B) summary statistics for both non-financial and financial firms for the variables used for the pre and post-announcement empirical analysis are presented. In panel A (pre-announcement) for non-financial firms the average price discount for the 232 deals is 29.1 percent showing clear evidence of the large price discounts typically found in right issues announcements. On average debt accounts for 25.9 percent of firm's total assets and close to 40 percent of companies had a negative return on assets prior to the announcement with 60 percent of the cases coinciding with a positive market sentiment. In the analysis of the market reaction to discount sizes (in what we term the post-announcement period), the cumulative abnormal returns are negative (2.8 percent) on average. Around only 30 percent of the firm's shares are held by majority shareholders,-showing a substantial ownership dispersion. In 60 percent of the cases the firm's cumulative return in prior 90 days to the announcement is positive.

[Please insert Table 3 panels $\mathrm{A}$ and $\mathrm{B}$ here]

In panel B summary statistics for financial firms are presented to the 36 deals observed during the period 1994 to 2012. In general, the results do not differ substantially from nonfinancial firms counterparts. However, we can highlight the average lower price discount for financial firms, with a lower median and close to half of the value for the first quartile of deals (6.1 and 10.9 percent for financial and non-financial firms, respectively). Financial firms are more leveraged, have lower bid-ask spread (less volatile/higher liquidity), are larger than non-financial firms and their ownership is almost as concentrated as those. Therefore, due to the highlighted differences between the two sub-samples it will be interesting to perform independent regressions to assess whether the variables used in this paper will impact differently on price discounts and cumulative abnormal returns.

Table 4 (panels A and B) presents the Pearson and Spearman correlation matrixes ${ }^{12}$ for nonfinancial and financial firms (p-values in parenthesis). Both sub-samples show that larger firms are more profitable, less volatile (lower bid-ask spread) and they are less likely to report losses. Also more profitable firms have lower bid-ask spread and firms with higher levels of

\footnotetext{
${ }^{12}$ Values for the Pearson and Spearman correlation matrixes are presented below and above the diagonal, respectively.
} 
debt are associated with better growth opportunities. Moreover larger financial firms have lower debt levels and more concentrated firms have higher levels of debt. For non-financial firms larger companies are less concentrated and more concentrated firms have a wider bidask spread, situations not statistical significant for financial firms. Finally firm ownership concentration is positively related with growth opportunities for financial firms and negatively for non-financial firms.

[Please insert Table 4 panels A and B here]

\section{Results}

\subsection{Determinants of Price Discounts}

Table 5 reports the cross-section regression estimates of price discounts for both nonfinancial and financial firms' deals according to the basic test equation (1) presented in section 3. Four different regressions are estimated with the use of different sets of variables. The first column named "model 1" presents the results for the variable Leverage. For the other columns/models we add one by one the additional variables reported in the previous section, which were argued to be potential determinants of the price discount level prior to announcement: Bid-Ask, Loss and M_Sentiment.

Overall, the coefficients are statistically significant and no differences were found in the predicted signs presented previously in table 1, for non-financials and financials firms, besides the variable Leverage. Indeed, the strong effect of Leverage on price discount for non-financial firms is not observed for financial firms ${ }^{13}$. For non-financial firms higher levels of debt, larger bid-ask spreads and recent losses increase the price discount for the new shares, whereas for financial firms only bid-ask spreads and reported losses have a similar statistical significance with the expected $\operatorname{sign}^{14}$.

[Please insert Table 5 here]

\footnotetext{
13 The coefficient for financial firms is negative, however not statistical significant.

${ }^{14}$ In a separate analysis, we studied whether the relative magnitude of the issue would be also a relevant variable in the regression. Unreported results (tables available upon request) show that the coefficients of the main variables maintain their signs and significance. However, missing observations in our database reduced in some magnitude the number of observations, especially in the case of financial companies, so this variable was not included in the main analysis.
} 
Table 6 (panels A and B) shows the results for the ordered probit model presented in section 4, equation 2. The price discount is divided by terciles for both non-financials and financials sub-samples. For non-financial firms the cut-off for the first and third terciles is 12.3 and 24.38 percent, respectively whereas for financial firms the values are 7.37 and 20.93 percent. The use of an ordered probit model in our analysis allows estimating the probability to apply a low, medium or large price discount due to changes in explanatory variables.

[Please insert Table 6 panels A and B here]

The results are quite interesting and bring insights in terms of the role of Leverage in price discounts, differentiating among non-financial and financial firms. In fact, each one percent rises in leverage for non-financial firms increases the probability of a larger price discount (i.e., a discount above 24.38 percent) by 0.332 percentage points and decrease the probability of lower price discount by 0.336 percentage points. Surprisingly, different results are obtained for financial firms where a one percent increase in Leverage decreases the probability of a larger price discount (i.e., a discount above 20.93 percent) by 0.445 percentage points and decrease the probability of lower price discount by 0.466 percentage points ${ }^{15}$. We interpret this difference between financial and non-financial firms as being consistent with the idea that, all else constant, the benefits of equity capital for banks with low equity ratios are perceived by investors as strong enough to incentive these to take up the new shares even with relatively low discounts. This is probably because equity issues directly impact on the ability of financial firms to expand their lending activities. For the remaining variables (Bid-ask, Loss and M_Sentiment), losses reported in the last year increase the probability of larger discounts (third tercile), while bid-ask spread is not significant in explaining differences in the price discounts levels. In addition, market sentiment is relevant for financial institutions but not for non-financial counterparts. A "good" market sentiment increases the probability for financial firms of practice larger price discounts by 0.252 percentage points.

\footnotetext{
${ }^{15}$ The role of leverage in price discount was highlighted already in the OLS regressions where no evidence was found for financial firms regarding higher levels of leverage and higher price discounts. Due to the few deals for financial firms the use of the ordered probit model brings additional evidence insights of the role of leverage in price discounts levels.
} 


\subsection{Post-announcement market reaction to price discounts}

In table 7 (panels A and B) we provide the results for the cumulative abnormal returns around the announcement of the right issues terms. In this table six different regressions are estimated with the use of different sets of variables. The first column named "model l" presents the results for the variable Price Discount our main explanatory variable. For the other columns/models we add one by one the control variables reported in the previous section. For non-financial firms the price discount has a negative statistical significant effect on the cumulative abnormal returns for all the different model specifications. Indeed, all else constant, a 1 percent increase in the price discount will negatively affect CARs by 5.3 percent. These results are in line with those reported by Burton et al. (2000), Slovin et al. (2000) and Armitage (2002) showing evidence that the announcement of right issues in the UK is seen as bad news by investors in the stock market and that part of this is caused by the price discount. This is consistent with the common perception among finance practitioners that this is a negative signal for the value of the company. However, our data does not warrant a similar conclusion in the case of financial firms as the price discount has only at best marginal significance in models used.

[Please insert Table 7 panels $\mathrm{A}$ and $\mathrm{B}$ here]

We also find positive statistical evidence of SIZE, TOBIN's $Q$ and F_SENTIMENT in explaining the CARs for non-financial firms. The results show that in larger firms the announcement of rights issues commands a more favourable impact on CARs. Additionally, an increase in future growth opportunities and positive market returns 90 days prior to the announcement also affects positively cumulative abnormal returns. For the Financial Firms sub-sample, the variables ROA and F_SENTIMENT are the most relevant explanatory variables for $C A R s$, being not just statistical significant but also with the predicted signs. Indeed, previous firm's performance addressed both in accounting and market terms have per se a positive impact in the way investors perceive the announcement of right issues. In summary, the results report clear evidence of the importance of price discount as a determinant of $C A R$ for both non-financial and financial firms, firm-characteristics better explain $C A R$ for non-financial firms and firm's prior market return is a statistically significant variable for both sub-samples. 


\section{Conclusions}

We document that price discounts in right issues for non- financial and financial firms are determined by a set of firm-characteristics and market sentiment (tables 5 and 6). We bring evidence that price discounts are not arbitrarily determined by firm managers. Indeed, our results shows that when determining price discounts managers take in consideration the firm's level of debt, the stock price volatility, the firm's recent financial performance, and the market conditions. Examining in detail how firm- characteristics affect price discounts we find that leverage impacts differently on non-financial and financial firms. In fact larger debt ratios prior to the right issues announcement for non-financial firms increase the probability of larger price discounts whereas this is not observed for the financial counterparts. We interpret this difference as consistent with the idea that the benefits of equity capital for financial institutions with low equity ratios are perceived by investors as strong enough to incentive these to take up the new shares even with relatively low discounts.

Following the discussion about price discounts and cumulative abnormal returns, nonfinancial firms have lower $C A R$ as the price discounts increases, but for financial companies such result is not statistically significant. We confirm the results from Burton et al. (2000), Slovin et al. (2000) and Armitage (2002) showing clear evidence that the announcement of right issues in the UK is seen as bad news by investors, and our evidence also supports the view that price discounts are indeed a major cause for this but only in the case of nonfinancial firms. We also document the importance of other firm-characteristics and market sentiment as determinants of post-announcement CARs for non-financial firms whereas for financial firms evidence was found for market sentiment and last year firm performance.

Overall, our results are consistent with the idea that in spite of the negative signal to investors conveyed by a significant price discount in the new shares, managers of non-financial companies still engage in substantially price-cutting. Our analysis shows that this occurs particularly when managers feel that the risks and costs and of an issue failure are high enough to compensate for the adverse reaction from the market to such discounts. This is more likely when companies face an adverse market climate, when their debt levels are high and when in the presence of losses. 


\section{References}

Altman, E., 1968, Financial Ratio, Discriminant Analysis and the Prediction of Corporate Bankruptcy, Journal of Finance, Vol. 23, Issue 4, pp. 589-609

Armitage, S., 1998, Seasoned Equity Offers and Rights Issues: A Review of the Evidence, European Journal of Finance, vol. 4, pp. 29-59

Armitage, 2002, Do Underwriters Certify Value? Evidence From UK Rights Issues and Open Offers, Journal of Business Finance and Accounting, Vol. 29, Nrs. 9\&10, pp. 12391273

Armitage, S., 2007, Discounts in Placing Pre-.Renounced Shares in Rights Issues, Journal of Business Finance and Accounting, Vol. 34, Nrs. 7\&8, pp. 1345-1369

Balanchadran, B., R. Faff, M. Theobald, E. Velayutham and P. Verwijmeren (2008), 'The Choice of Seasoned Equity Offerings Methods and Long Term Returns', Working Paper, EFA 2009 Bergen Meeting Paper

Balanchadran, B., R. Faff and M. Theobald (2008), Rights Offerings, Takeup, Renounceability, and Underwriting Status, Journal of Financial Economics, Vol. 89, No 2, pp. 328-346

Balanchadran, B., R. Faff and M. Theobald (2009), New Insights Into Rights Offerings as Signals of Firm Quality: Evidence From Australia, Journal of Applied Corporate Finance, Vol. 21, No 3, pp. 80-85

Beatty, R.., and J.. Ritter, 1986, Investment banking, reputation, and the underpricing of initial public offerings, Journal of Financial Economics, Vol. 15, pp. 213-232.

Bohren, O, B. Eckbo and. Michalsen (1997), Why Underwrite Rights Offerings? Some New Evidence, Journal of Financial Economics, Vol. 46, No 2, pp. 223-261

Brigham, E., 1986, Financial Management - Theory and Practice, $4^{\text {th }}$ Edition, Holt-Saunders International Edition

Burton, B. M., A. A. Lonie and D. M. Power (1999), Does the Issue Method Influence the Market Reaction to Seasoned Equity Offer Announcements?, Applied Economics Letters, Vol. 6, No.7, pp. 459-62.

Capstaff , J. and J. Fletcher, John, 2011, Long Term Performance and Choice of SEO Method by UK Firms, Journal of Business Finance \& Accounting, Vol. 38, Nr. 9-10, pp. 1262-1289

Christie, A. , 1982, The stochastic behavior of common stock variances: Value, leverage and interest rate effects, Journal of Financial Economics, Vol. 10, Nr. 4, pp. 407-432.

Copeland, T. and Galai, D., 1983, Information Effects on the Bid-Ask Spread, Journal of Finance, Vol. 38, Nr. 5, pp.1457-1469

Corwin, S. A., 2003, The Determinants of Underpricing for Seasoned Equity Offers, Journal of Finance, Vol. 58, Nr. 5, pp. 2249-2279

Dahl, D., and R. Shrieves, 1990, The impact of regulation on bank equity infusions. Journal of Banking \& Finance, Vol. 14, Nr. 6, pp. 1209-1228.

Eckbo, B. E. and R. W. Masulis (1995), Seasoned Equity Offerings: A Survey, in R. Jarrow, V. Maksimovic and W. T. Ziemba (eds.) Handbooks in Operation Research and Management, Science: Finance (Elsevier Science, Amsterdam, North Holland), Vol. 9, pp. 1017-72.

Eckbo, R., and R. Masulis (1997), Adverse Selection and the Rights Offer Paradox, Journal of Financial Economics, Vol. 32, No 3, pp. 293-332

Espenlaub, S., A. Iqbal and N. Strong, 2009, Datastream Returns And UK Open Offers, Eurpean Journal of Finance, Vol. 15. Nr.1, pp. 61-69

Flanagan, M. (2009), Hefty Discount on Rights Issues, The Scotsman online, 24 September 2009 
Gao, X., and J. Ritter, 2010, The Marketing of Seasoned Equity Offerings." Journal of Financial Economics, Vol. 97, pp. 33-52.

Gerard, B., and V. Nanda, 1993, Trading and manipulation around seasoned equity offerings, Journal of Finance, Vol. 48, pp. 213-245.

Ginglinger, E., L. Matsoukis and F. Riva, 2013, Seasoned Equity Offerings: Stock Market Liquidity and the Rights Offerings Paradox, Journal of Business Finance and Accounting, Vol. 40, pp. 215-238

Heinkel, L. and E. Schwartz (1986), Rights Versus Unverwritten Offerings: An Asymmetric Approach, Journal of Finance, Vol. 41, No 1, pp. 1-18

Huang, R. and D. Zhang, 2011, Managing Underwriters and the Marketing of Seasoned Equity Offerings, Journal of Financial and Quantitative Analysis, Vol. 46, pp. 141-70.

Iqbal, A. (2008), The Importance of the Sequence in UK Rights Issues, Journal of Business Finance \& Accounting, Vol. 35, No. 1-B. 2, pp. 150-176.

Kabir, R., and P. Roosenboom, 2003, Can the stock market anticipate future operating performance? Evidence from equity rights issues, Journal of Corporate Finance, Vol. 9, nr. 1, pp. 93-113

La Porta, R., F. Lopez-de-Silanes, A. Schleifer, 2000, Investor Protection and Corporate Governance, Journal of Financial Economics, Vol. 58, Issues 1-2, 2000, Pages 3-27

Lee, I., S. Lochhead, J. Ritter, and Q. Zhao, 1996, The costs of raising capital, Journal of Financial Research, Vol. 19, pp. 59-74.

Levis, M. (1995), Seasoned Equity Offerings and the and the short- and long-run performance of initial public offerings in the UK, European Financial Management, Vol. 1, Issue 2, pp. 125-146.

Loderer, C., J. Cooney, and L. Van Drunen, 1991, The price elasticity of demand for common stock, Journal of Finance, Vol. 46, pp. 621-651.

Marsden, A. (2000), Shareholder wealth effects of rights issues:Evidence from the New Zealand capital market, Pacific-Basin Finance Journal, Vol. 8, pp. 419-442

Marsh, P., 1980, Valuation of Underwriting Agreements for UK Rights Issues, Journal of Finance, Vol. 35, nr. 3, pp. 693-716

Maug, E., 1998, Large Shareholders as Monitors: Is There a Trade-Off between Liquidity and Control?, Journal of Finance, Vol. 53, nr. 1, pp. 65-98

Nevis, M., 1995, Seasoned equity offerings and the short- and long-run performance of initial public offerings in the UK, European Financial Management, Vol. 1, Nr. 2, pp. 125146

Singh, A. (1997), Layoffs and Underwritten Rights Offers, Journal of Financial Economics, Vol. 43, No.1, pp. 105-30.

Slovin, B. , M. Sushka and K. Lai (2000), Alternative Flotation Methods, Adverse Selection and Ownership Structure: Evidence from Seasoned Equity Issuance in the UK, Journal of Financial Economics, Vol. 57, Nr. 2, pp. 157-190

Office of Fair Trading, 2011, Equity Underwriting and Associated Services, OFT1303 Working Paper

Rock, K., 1986, Why new issues are underpriced, Journal of Financial Economics Vol.15, pp. 187-212

Scholes, M., 1972, The market for securities: Substitution versus price pressure and the effects of information on share prices, Journal of Business, Vol. 45, pp. 179-211. 
Table 1: Variables Definition and expected relationship with price discount

\begin{tabular}{|c|c|c|}
\hline Variables & Description & Expected Sign \\
\hline \multicolumn{3}{|c|}{ Pre-announcement } \\
\hline Price Discount & Price Discount $=1-($ issue price divided by last price $)$ & $\begin{array}{l}\text { Dependent } \\
\text { Variable }\end{array}$ \\
\hline Leverage & Leverage $=$ Total debt divided by total assets & $(+)$ \\
\hline Bid_Ask & $\begin{array}{l}\text { Stock's bid -ask spread in the } 260 \text { days prior to the right } \\
\text { issue announcement }\end{array}$ & $(+)$ \\
\hline Loss & $\begin{array}{l}\text { Binary variable equal to one if return on assets is } \\
\text { negative and zero otherwise }\end{array}$ & $(+)$ \\
\hline M_Sentiment & $\begin{array}{l}\text { Binary variable equal to one if last year market return } \\
\text { (previous to announcement) is positive and zero } \\
\text { otherwise }\end{array}$ & $(-)$ \\
\hline
\end{tabular}

Table 2: Variables Definition and expected relationship with Cumulative Abnormal Returns

\begin{tabular}{|c|c|c|}
\hline Variables & Description & Expected Sign \\
\hline \multicolumn{3}{|c|}{ Post-announcement } \\
\hline CAR_Rights & $\begin{array}{l}\text { Cumulative abnormal returns around announcement of } \\
\text { rights issues terms }\end{array}$ & $\begin{array}{l}\text { Dependent } \\
\text { Variable }\end{array}$ \\
\hline Price Discount & Price Discount $=1-$ (issue price divided by last price $)$ & $(-)$ \\
\hline Size & Natural logarithm of firm's market value & $(+)$ \\
\hline ROA & $\begin{array}{l}\text { Return on Assets = Net Income divided by lagged total } \\
\text { assets }\end{array}$ & $(+)$ \\
\hline Tobin's $Q$ & $\begin{array}{l}\text { Market value of Equity plus Book value of Debt divided } \\
\text { by book value of debt and Equity }\end{array}$ & $(+)$ \\
\hline C_Held_Shares & $\begin{array}{l}\text { Closely held shares }=\text { percentage shares held by } \\
\text { majority shareholders }\end{array}$ & $(-) /(+)$ \\
\hline F_Sentiment & $\begin{array}{l}\text { Binary variable equal to one if firm's cumulative return } \\
\text { in prior } 90 \text { days to announcement is positive and zero } \\
\text { otherwise }\end{array}$ & $(+)$ \\
\hline
\end{tabular}


Table 3: Summary Statistics

Panel A: Non-Financials

\begin{tabular}{|c|c|c|c|c|c|c|c|}
\hline Variables & Mean & Std. Dev. & $\mathbf{1}^{\text {st }}$ Quartile & Median & $\mathbf{3}^{\text {rd }}$ Quartile & Min & Max \\
\hline $\begin{array}{l}\text { Pre-announcement } \\
\text { Price Discount }\end{array}$ & 0.291 & 0.291 & 0.109 & 0.159 & 0.328 & 0.012 & 0.989 \\
\hline Leverage & 0.259 & 0.193 & 0.122 & 0.239 & 0.342 & 0.000 & 0.917 \\
\hline Bid_ask & 0.052 & 0.057 & 0.017 & 0.030 & 0.064 & 0.002 & 0.301 \\
\hline Loss & 0.388 & 0.488 & 0 & 0 & 1 & 0 & 1 \\
\hline M_Sentiment & 0.608 & 0.489 & 0 & 1 & 1 & 0 & 1 \\
\hline Variables & Mean & Std. Dev. & $1^{\text {st }}$ Quartile & Median & $3^{\text {rd }}$ Quartile & Min & Max \\
\hline \multicolumn{8}{|l|}{ Post-announcement } \\
\hline CAR_Rights & -0.028 & 0.106 & -0.074 & -0.016 & 0.035 & -0.512 & 0.214 \\
\hline Size & 4.253 & 1.836 & 3.006 & 4.302 & 5.508 & -0.073 & 9.134 \\
\hline$R O A$ & -0.059 & 0.433 & -0.110 & 0.034 & 0.096 & -3.100 & 0.883 \\
\hline Tobin's $Q$ & 3.317 & 3.696 & 1.381 & 2.006 & 3.468 & 0.228 & 18.872 \\
\hline C_Held_Shares & 0.297 & 0.216 & 0.126 & 0.254 & 0.425 & 0.000 & 0.903 \\
\hline F_Sentiment & 0.599 & 0.491 & 0 & 1 & 1 & 0 & 1 \\
\hline
\end{tabular}

Panel B: Financials

\begin{tabular}{|c|c|c|c|c|c|c|c|}
\hline Variables & Mean & Std. Dev. & $1^{\text {st }}$ Quartile & Median & $3^{\text {rd }}$ Quartile & Min & Max \\
\hline
\end{tabular}

Pre-announcement 


$\begin{array}{lcccccr}\text { Price Discount } & 0.245 & 0.276 & 0.061 & 0.125 & 0.305 & 0.012 \\ \text { Leverage } & 0.326 & 0.289 & 0.017 & 0.387 & 0.520 & 0.000 \\ \text { Bid_ask } & 0.036 & 0.030 & 0.013 & 0.029 & 0.052 \\ \text { Loss } & 0.333 & 0.478 & 0 & 0 & 1 \\ \text { M_Sentiment } & 0.694 & 0.467 & 0 & 1 & 0.116 \\ & & & 0 & 1\end{array}$

\begin{tabular}{|c|c|c|c|c|c|c|c|}
\hline Variables & Mean & Std. Dev. & $\mathbf{1}^{\text {st }}$ Quartile & Median & $3^{\text {rd }}$ Quartile & Min & Max \\
\hline \multicolumn{8}{|c|}{ Post-announcement } \\
\hline CAR_Rights & -0.036 & 0.127 & -0.061 & -0.012 & 0.016 & -0.512 & 0.214 \\
\hline Size & 4.956 & 2.059 & 3.577 & 4.915 & 6.020 & -0.073 & 9.134 \\
\hline$R O A$ & -0.018 & 0.257 & -0.010 & 0.009 & 0.031 & -1.416 & 0.311 \\
\hline Tobin's $Q$ & 2.409 & 3.526 & 1.001 & 1.355 & 1.641 & 0.820 & 18.783 \\
\hline C_Held_Shares & 0.255 & 0.257 & 0.028 & 0.180 & 0.366 & 0.000 & 0.798 \\
\hline F_Sentiment & 0.639 & 0.487 & 0 & 1 & 1 & 0 & 1 \\
\hline
\end{tabular}


Table 4: Pearson and Spearman Correlation Matrix

The sample consists of 232 and 36 deals for non-financial and financial firms, respectively, over the period 1994-2012. Values for the Pearson and Spearman correlation matrixes are presented below and above the diagonal, respectively. $P$-values are in parenthesis. Superscript* indicate statistical significant at $0.01(* * *), 0.05(* *)$ and 0.10

(*).

Panel A: Non-Financials

CAR_Rights $\quad$ Price Discount

Size Tobin's $Q \quad$ Leverage

\begin{tabular}{|c|c|c|c|c|c|c|c|c|c|c|c|}
\hline CAR_Rights & 1 & $-0.247 * * *$ & 0.114 & $0.200 * *$ & 0.0265 & $0.133^{*}$ & 0.082 & -0.096 & -0.126 & $0.210^{* *}$ & $0.142 *$ \\
\hline Price Discount & $-0.154^{*}$ & 1 & -0.035 & -0.129 & $0.167 *$ & $-0.279 * * *$ & -0.020 & $0.189^{* *}$ & $0.285 * * *$ & -0.088 & -0.036 \\
\hline Size & $0.173 * *$ & $-0.153 *$ & 1 & $0.325 * * *$ & -0.011 & $0.332 * * *$ & $-0.490 * * *$ & $-0.840 * * *$ & $-0.316^{* * *}$ & $0.178 * *$ & 0.0032 \\
\hline Tobin's $Q$ & $0.163 *$ & 0.039 & 0.121 & 1 & $-0.226 * * *$ & $0.350 * * *$ & -0.100 & $-0.300 * * *$ & $-0.230 * * *$ & $0.237 * * *$ & 0.068 \\
\hline Leverage & 0.006 & $0.221 * * *$ & 0.003 & $-0.163^{*}$ & 1 & -0.010 & -0.023 & -0.007 & 0.017 & -0.090 & -0.028 \\
\hline$R O A$ & -0.001 & $-0.226 * * *$ & $0.208 * *$ & -0.059 & -0.080 & 1 & -0.090 & $-0.455 * * *$ & $-0.844 * * *$ & $0.255^{* * *} *$ & -0.037 \\
\hline C_Held_Shares & -0.003 & 0.0857 & $-0.455^{* * *}$ & 0.012 & -0.011 & -0.075 & 1 & $0.426^{* * *}$ & 0.089 & -0.016 & 0.053 \\
\hline Bid_Ask & -0.098 & $0.317 * * *$ & $-0.684 * * *$ & -0.051 & 0.040 & $-0.278 * * *$ & $0.302 * * *$ & 1 & $0.450 * * *$ & $-0.138 *$ & 0.036 \\
\hline Loss & $-0.145^{*}$ & $0.274 * * *$ & $-0.303^{* * *}$ & 0.052 & 0.025 & $-0.499 * * *$ & 0.106 & $0.382 * * *$ & 1 & $-0.251 * * *$ & 0.024 \\
\hline M_Sentiment & $0.221 * * *$ & -0.071 & $0.185^{* *}$ & $0.183^{* *}$ & -0.078 & 0.123 & -0.034 & -0.055 & $-0.251 * * *$ & 1 & 0.063 \\
\hline F_Sentiment & 0.123 & 0.052 & -0.015 & 0.099 & -0.030 & -0.022 & 0.039 & 0.011 & 0.024 & 0.063 & 1 \\
\hline
\end{tabular}


Panel B: Financials

\begin{tabular}{|c|c|c|c|c|c|c|c|c|c|c|c|}
\hline & CAR_Rights & Price Discount & Size & Tobin's $Q$ & Leverage & $R O A$ & C_Held_Shares & Bid_Ask & Loss & M_Sentiment & F_Sentiment \\
\hline CAR_Rights & 1 & -0.282 & 0.127 & $0.351 *$ & -0.220 & $0.403 *$ & 0.212 & -0.075 & $-0.420^{*}$ & $0.454 * *$ & $0.363^{*}$ \\
\hline Price Discount & -0.198 & 1 & -0.065 & -0.316 & -0.113 & $-0.513 * *$ & $-0.469 * *$ & 0.126 & $0.596 * * *$ & -0.111 & -0.009 \\
\hline Size & 0.052 & -0.283 & 1 & 0.179 & $-0.399 *$ & 0.296 & -0.234 & $-0.894 * * *$ & -0.323 & 0.248 & -0.0377 \\
\hline Tobin's $Q$ & 0.174 & -0.087 & -0.176 & 1 & $-0.347 *$ & 0.132 & 0.320 & -0.171 & -0.119 & 0.053 & -0.003 \\
\hline Leverage & -0.176 & 0.0813 & $-0.579 * * *$ & -0.023 & 1 & -0.067 & 0.185 & $0.384 *$ & 0.040 & -0.059 & 0.142 \\
\hline$R O A$ & 0.267 & -0.169 & 0.174 & -0.172 & 0.179 & 1 & 0.282 & -0.267 & $-0.817 * * *$ & 0.320 & 0.311 \\
\hline C_Held_Shares & 0.189 & -0.329 & -0.250 & 0.243 & 0.299 & 0.093 & 1 & 0.264 & -0.261 & 0.156 & 0.247 \\
\hline Bid_Ask̄ & -0.067 & $0.504 * *$ & $-0.863 * * *$ & 0.121 & $0.528 * * *$ & -0.124 & 0.101 & 1 & $0.363^{*}$ & -0.217 & 0.058 \\
\hline Loss & -0.188 & $0.693 * * *$ & -0.318 & 0.243 & 0.046 & $-0.404^{*}$ & -0.256 & $0.437 * *$ & 1 & $-0.450 * *$ & -0.298 \\
\hline M_Sentiment & $0.450 * *$ & -0.242 & 0.263 & -0.083 & -0.071 & 0.227 & 0.145 & -0.239 & $-0.450 * *$ & 1 & $0.380 *$ \\
\hline F_Sentiment & $0.358^{*}$ & -0.090 & -0.077 & -0.156 & 0.190 & 0.254 & 0.274 & 0.071 & -0.298 & $0.380 *$ & 1 \\
\hline
\end{tabular}


Table 5: Pre-announcement Multivariate Regression Results for Price Discount

Table shows cross section analysis of price discounts. The following model is estimated: Price Discount $i_{i, t}=\alpha+\beta_{1}$ Leverage $_{i, t}+\beta_{2}$ Bid_Ask $_{i, t}+\beta_{3}$ Loss $_{i, t}+$ $\beta_{4} M_{-}$Sentiment $_{i, t}+\varepsilon_{i, t}$ by OLS. Estimation period is from 1994 to 2012 . The dependent variable is price discount defined as one minus the issue price divided by the last available price. Reported t-statistics (in parenthesis) are calculating using heteroskedasticity-robust standard errors (White). Superscript $*$ indicate statistical significance at $0.01(* *), 0.05(* *)$ and $0.10(*)$.

\begin{tabular}{lcccc}
\hline Non-Financials & Model (1) & Model (2) & Model (3) & Model (4) \\
\hline \multirow{3}{*}{ Leverage } & & & & \\
& $0.333^{* * *}$ & $0.315^{* * *}$ & $0.312^{* * *}$ & $0.315^{* * *}$ \\
Bid-Ask & $(2.931)$ & $(2.997)$ & $(2.988)$ & $(3.007)$ \\
& & $1.575^{* * *}$ & $1.232^{* * *}$ & $1.231^{* * *}$ \\
Loss & & $(3.671)$ & $(2.712)$ & $(2.709)$ \\
& & & $0.105^{* *}$ & $0.104^{* *}$ \\
M_Sentiment & & & $(2.323)$ & $(2.319)$ \\
& & & & 0.031 \\
Constant & $0.205^{* * *}$ & $0.128^{* * *}$ & $0.106^{* * *}$ & $0.087^{* *}$ \\
& $(6.555)$ & $(4.046)$ & $(3.662)$ & $(2.310)$ \\
& & & & \\
Observations & 232 & 232 & 232 & 232 \\
$R$-squared & 0.049 & 0.144 & 0.17 & 0.173 \\
\hline
\end{tabular}

\begin{tabular}{lcccc}
\hline Financials & Model (1) & Model (2) & Model (3) & Model (4) \\
\hline \multirow{2}{*}{ Leverage } & & & & \\
& 0.078 & -0.245 & -0.108 & -0.118 \\
Bid-Ask & $(0.389)$ & $(-1.641)$ & $(-0.898)$ & $(-0.935)$ \\
& & $5.894^{* * *}$ & $2.942^{* *}$ & $2.796^{*}$ \\
Loss & & $(3.603)$ & $(2.051)$ & $(2.029)$ \\
& & & $0.323^{* * *}$ & $0.342^{* * *}$ \\
M_Sentiment & & & $(3.236)$ & $(3.860)$ \\
& & & & 0.052 \\
Constant & $0.220^{* * *}$ & $0.111^{*}$ & 0.066 & $0.627)$ \\
& $(3.431)$ & $(1.869)$ & $(1.357)$ & 0.032 \\
& & & & \\
Observations & 36 & 36 & 36 & 36 \\
$R$-squared & 0.007 & 0.301 & 0.539 & 0.546 \\
\hline
\end{tabular}


Table 6: Pre-announcement Ordered probit Results for Price Discount

Panel A: Table shows ordered probit analyses of price discount. Price discount is divided in terciles. Estimation period is from 1994 to 2012 . The dependent variable is price discount defined as one minus the issue price divided by the last available price. Reported t-statistics (in parenthesis).. Dependent variable is price discount defined as one minus the issue price divided by the last available price. Reported t-statistics (in parenthesis). Superscript $*$ indicate statistical significance at $0.01(* * *), 0.05(* *)$ and 0.10 $(*)$.

\begin{tabular}{|c|c|c|c|c|}
\hline Non-Financials & Model (1) & Model (2) & Model (3) & Model (4) \\
\hline Leverage & $\begin{array}{c}1.026 * * * \\
(2.597)\end{array}$ & $\begin{array}{l}1.009 * * \\
(2.562)\end{array}$ & $\begin{array}{l}1.006 * * \\
(2.496)\end{array}$ & $\begin{array}{c}0.979 * * \\
(2.440)\end{array}$ \\
\hline Bid-Ask & & $\begin{array}{l}3.269 * * \\
(2.000)\end{array}$ & $\begin{array}{c}1.636 \\
(0.978)\end{array}$ & $\begin{array}{c}1.656 \\
(0.981)\end{array}$ \\
\hline Loss & & & $\begin{array}{c}0.497 * * * \\
(2.786)\end{array}$ & $\begin{array}{c}0.502 * * * \\
(2.802)\end{array}$ \\
\hline M_Sentiment & & & & $\begin{array}{c}-0.211 \\
(-1.392)\end{array}$ \\
\hline Cut 1 & $\begin{array}{c}-0.168 \\
(-1.314)\end{array}$ & $\begin{array}{c}-0.0124 \\
(-0.0880)\end{array}$ & $\begin{array}{l}0.0821 \\
(0.577)\end{array}$ & $\begin{array}{l}-0.0495 \\
(-0.298)\end{array}$ \\
\hline Cut 2 & $\begin{array}{c}0.706^{* * * *} \\
(5.321)\end{array}$ & $\begin{array}{c}0.875^{* * * *} \\
(5.905)\end{array}$ & $\begin{array}{c}0.993 * * * \\
(6.702)\end{array}$ & $\begin{array}{c}0.867 * * * \\
(5.102)\end{array}$ \\
\hline Wald Chi2 & 6.744 & 11.31 & 21.23 & 22.24 \\
\hline Pseudo R-squared & 0.014 & 0.025 & 0.043 & 0.047 \\
\hline
\end{tabular}

\begin{tabular}{lcccc}
\hline Financials & Model (1) & Model (2) & Model (3) & Model (4) \\
\hline Leverage & -0.845 & $-1.792^{* *}$ & $-1.526^{* *}$ & $-1.736^{* *}$ \\
& $(-1.076)$ & $(-2.397)$ & $(-2.133)$ & $(-2.154)$ \\
Bid-Ask & & $16.80^{* *}$ & 6.907 & 3.701 \\
& & $(2.228)$ & $(0.838)$ & $(0.416)$ \\
Loss & & & $1.336^{* *}$ & $1.815^{* * *}$ \\
& & & $(2.208)$ & $(2.843)$ \\
M_Sentiment & & & & $0.982^{*}$ \\
& & & & $(1.818)$ \\
\hline Cut 1 & $-0.718^{* *}$ & -0.472 & -0.406 & 0.194 \\
& $(-2.192)$ & $(-1.295)$ & $(-1.124)$ & $(0.383)$ \\
Cut 2 & & & & \\
& 0.167 & 0.496 & $0.700^{*}$ & $1.417^{* * *}$ \\
& $(0.549)$ & $(1.410)$ & $(1.957)$ & $(2.915)$ \\
Wald Chi2 & & & & \\
\hline Pseudo R-squared & 0.020 & 0.078 & 0.172 & 0.221 \\
\hline
\end{tabular}


Panel B: Shows the marginal effects for the ordered probit regressions. Predict outcome 0 to 2 represents the probability of price discount in each of the terciles due to change in variables, Leverage, Bid-Ask, Loss and M Sentiment. Estimation period is from 1994 to 2012. Dependent variable is price discount defined as one minus the issue price divided by the last available price. Reported t-statistics (in parenthesis). Superscript * indicate statistical significance at $0.01(* * *), 0.05(* *)$ and $0.10(*)$.

\begin{tabular}{lccc} 
Non-Financials & Predict Outcome (0) & Predict Outcome (1) & Predict Outcome (2) \\
\hline Leverage & $-0.336^{* *}$ & 0.004 & $0.332^{* *}$ \\
\multirow{2}{*}{ Bid_Ask } & $(2.51)$ & $(0.19)$ & $(2.48)$ \\
& -0.568 & 0.006 & 0.562 \\
Loss & $(0.99)$ & $(0.19)$ & $(0.98)$ \\
& $-0.172^{* * *}$ & 0.002 & $0.170^{* * *}$ \\
M_Sentiment & $(2.9)$ & $(0.19)$ & $(2.89)$ \\
& 0.072 & -0.001 & -0.072 \\
& $(1.4)$ & $(0.19)$ & $(1.41)$
\end{tabular}

\begin{tabular}{lccc} 
Financials & Predict Outcome (0) & Predict Outcome (1) & Predict Outcome (2) \\
\hline Leverage & $0.466^{* *}$ & -0.021 & $-0.445^{* *}$ \\
& $(2.3)$ & $(0.37)$ & $(2.16)$ \\
Bid_Ask & -0.993 & 0.044 & 0.948 \\
& $(0.41)$ & $(0.26)$ & $(0.42)$ \\
Loss & $-0.487^{* * *}$ & 0.022 & $0.465^{* * *}$ \\
\multirow{2}{*}{ M_Sentiment } & $(3.57)$ & $(0.36)$ & $(3.69)$ \\
& $-0.263^{*}$ & 0.012 & $0.252^{*}$ \\
& $(1.93)$ & $(0.38)$ & $(1.83)$ \\
\hline
\end{tabular}


Table 7: Post-announcement Multivariate Regression Results for CAR

Panel A: Non-Financials

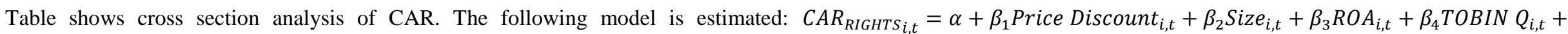
$\beta_{5} C_{-}$Held_Shares $s_{i, t}+\beta_{6} F_{-}$Sentiment $_{i, t}+\varepsilon_{i, t}$ by OLS. Estimation period is from 1994 to 2012. Dependent variable is Cumulative Abnormal Returns (CAR). Reported tstatistics (in parenthesis) are calculating using heteroskedasticity-robust standard errors (White). Superscript * indicate statistical significance at 0.01 (***), $0.05(* *)$ and $0.10(*)$.

\begin{tabular}{|c|c|c|c|c|c|c|}
\hline Variables & Model (1) & Model (2) & Model (3) & Model (4) & Model (5) & Model (6) \\
\hline \multirow[t]{2}{*}{ Price Discount } & $-0.056^{*}$ & $-0.048 *$ & $-0.051^{*}$ & $-0.055^{*}$ & $-0.055^{*}$ & $-0.053^{*}$ \\
\hline & $(-1.929)$ & $(-1.659)$ & $(-1.739)$ & $(-1.932)$ & $(-1.969)$ & $(-1.940)$ \\
\hline \multirow[t]{2}{*}{ Size } & & $0.009 * *$ & $0.008^{* *}$ & $0.008 * *$ & $0.011 * *$ & $0.009 * *$ \\
\hline & & $(2.422)$ & (2.191) & $(2.267)$ & $(2.536)$ & $(2.191)$ \\
\hline \multirow[t]{2}{*}{ Tobin's $Q$} & & & $0.004 * *$ & $0.004 * *$ & $0.004 * *$ & $0.003 *$ \\
\hline & & & $(2.412)$ & $(2.310)$ & $(2.186)$ & $(1.721)$ \\
\hline \multirow[t]{2}{*}{$R O A$} & & & & -0.014 & -0.014 & -0.018 \\
\hline & & & & $(-0.651)$ & $(-0.670)$ & $(-0.907)$ \\
\hline \multirow[t]{2}{*}{ C_Held_Shares } & & & & & 0.043 & 0.039 \\
\hline & & & & & (1.107) & $(1.015)$ \\
\hline \multirow[t]{2}{*}{ F_Sentiment } & & & & & & $0.037 * * *$ \\
\hline & & & & & & $(2.715)$ \\
\hline \multirow[t]{2}{*}{ Constant } & -0.011 & $-0.052 * * *$ & $-0.060 * * *$ & $-0.062 * * *$ & $-0.084 * * *$ & $-0.097 * * *$ \\
\hline & $(-1.346)$ & $(-2.624)$ & $(-3.007)$ & $(-3.054)$ & $(-3.060)$ & $(-3.444)$ \\
\hline$R$-squared & 0.024 & 0.047 & 0.069 & 0.072 & 0.078 & 0.106 \\
\hline
\end{tabular}


Panel B: Financials

\begin{tabular}{|c|c|c|c|c|c|c|}
\hline Variables & Model (1) & Model (2) & Model (3) & Model (4) & Model (5) & Model (6) \\
\hline Price Discount & $\begin{array}{c}-0.091 \\
(-1.390)\end{array}$ & $\begin{array}{c}-0.092 \\
(-1.460)\end{array}$ & $\begin{array}{c}-0.081 \\
(-1.205)\end{array}$ & $\begin{array}{c}-0.061 \\
(-0.892)\end{array}$ & $\begin{array}{c}-0.044 \\
(-0.462)\end{array}$ & $\begin{array}{c}-0.025 \\
(-0.275)\end{array}$ \\
\hline Size & & $\begin{array}{c}-0.000 \\
(-0.034)\end{array}$ & $\begin{array}{c}0.002 \\
(0.233)\end{array}$ & $\begin{array}{c}0.000 \\
(0.021)\end{array}$ & $\begin{array}{c}0.002 \\
(0.268)\end{array}$ & $\begin{array}{c}-0.004 \\
(-0.450)\end{array}$ \\
\hline Tobin's $Q$ & & & $\begin{array}{c}0.006 \\
(0.880)\end{array}$ & $\begin{array}{c}0.008 \\
(1.040)\end{array}$ & $\begin{array}{c}0.007 \\
(1.051)\end{array}$ & $\begin{array}{c}0.008 \\
(1.682)\end{array}$ \\
\hline$R O A$ & & & & $\begin{array}{c}0.139 * * * \\
(4.620)\end{array}$ & $\begin{array}{c}0.134^{* * * *} \\
(4.602)\end{array}$ & $\begin{array}{r}0.104^{* * * *} \\
(3.396)\end{array}$ \\
\hline C_Held_Shares & & & & & $\begin{array}{c}0.046 \\
(0.474)\end{array}$ & $\begin{array}{c}0.009 \\
(0.123)\end{array}$ \\
\hline F_Sentiment & & & & & & $\begin{array}{l}0.110^{*} \\
(1.953)\end{array}$ \\
\hline Constant & $\begin{array}{c}-0.013 \\
(-0.530)\end{array}$ & $\begin{array}{c}-0.012 \\
(-0.250)\end{array}$ & $\begin{array}{c}-0.040 \\
(-0.772)\end{array}$ & $\begin{array}{c}-0.038 \\
(-0.745)\end{array}$ & $\begin{array}{c}-0.063 \\
(-0.758)\end{array}$ & $\begin{array}{l}-0.100 \\
(-1.161)\end{array}$ \\
\hline$R$-squared & 0.039 & 0.039 & 0.065 & 0.138 & 0.145 & 0.297 \\
\hline
\end{tabular}

